\title{
Spindle-cell carcinoma of the prostate
}

\author{
Carlos Hirokatsu Watanabe Silva ${ }^{a}$, Oliver Rojas Claros ${ }^{a}$, Isaac Amselem ${ }^{b}$, \\ Newton Soares Sá Filho ${ }^{b}$, Oscar Eduardo Hidetoshi Fugita ${ }^{a, b}$
}

Silva CHW, Rojas Claros O, Amselem I, Sá Filho NS, Fugita OEH. Spindle-cell carcinoma of the prostate. Autopsy Case Rep [Internet]. 2012;2(1):55-61. http://dx.doi.org/10.4322/acr.2012.009

\section{ABSTRACT}

\begin{abstract}
Sarcoma of the prostate and sarcomatoid carcinoma of the prostate are rare conditions, both characterized by a poor prognosis. Sarcomatoid carcinoma of the prostate typically arise from the evolution of an underlying adenocarcinoma, occasionally featuring heterologous elements, bulky disease being possible but rare. In contrast, sarcoma of the prostate derives from non-epithelial mesenchymal components of the prostatic stroma, shows rapid growth, and frequently presents as massive pelvic tumors obstructing the urinary tract at the time of diagnosis. We report the case of a 55-year-old patient with a two-month history of symptoms of urinary obstruction. The patient presented with an extremely enlarged heterogeneous prostate, although his prostatespecific antigen level was low. The lack of a history of prostatic neoplasia led us to suspect sarcoma, and a transrectal prostate biopsy was carried out. An immunohistochemical study of the biopsy specimen did not confirm the clinical suspicion. However, in view of the clinical features, we believe that sarcoma of the prostate was the most likely diagnosis. The patient received neoadjuvant chemotherapy followed by radiation therapy. At this writing, surgical resection had yet to be scheduled.
\end{abstract}

Keywords: Prostate; Sarcoma; Carcinoma.

\section{CASE REPORT}

We report a case of a 55-year-old male patient who sought treatment in the Surgery Department Hospital. His primary complaint was acute urinary retention. He had a two-month history of symptoms of urinary obstruction. Physical examination revealed hard, lobulated enlargement of the prostate. Computed tomography (CT) scans of the abdomen and pelvis (Figures 1 and 2) showed an extremely enlarged heterogeneous prostate (estimated volume, $300 \mathrm{cc}$ ) without evidence of adjacent tissue invasion. At diagnosis, his serum prostatespecific antigen (PSA) level was $0.7 \mathrm{ng} \cdot \mathrm{mL}^{-1}$ (reference range, 0-4 ng. $\mathrm{mL}^{-1}$ ). Despite urinary catheterization, the patient developed renal failure. Another CT scan performed on postadmission day 10 showed rapid tumor growth, the volume of the prostate having increased to $700 \mathrm{cc}$.

\footnotetext{
${ }^{a}$ Department of Surgery - Hospital Universitário - Universidade de São Paulo - São Paulo/SP - Brazil

${ }^{b}$ Department of Urology - Hospital São Camilo - Santana - São Paulo/SP - Brazil.
}

Copyright $\odot 2012$ Autopsy and Case Reports - This is an Open Access article distributed of terms of the Creative Commons Attribution NonCommercial License (http://creativecommons.org/licenses/by/3.0/) which permits unrestricted non-commercial use, distribution, and reproduction in any médium provided article is properly cited. 


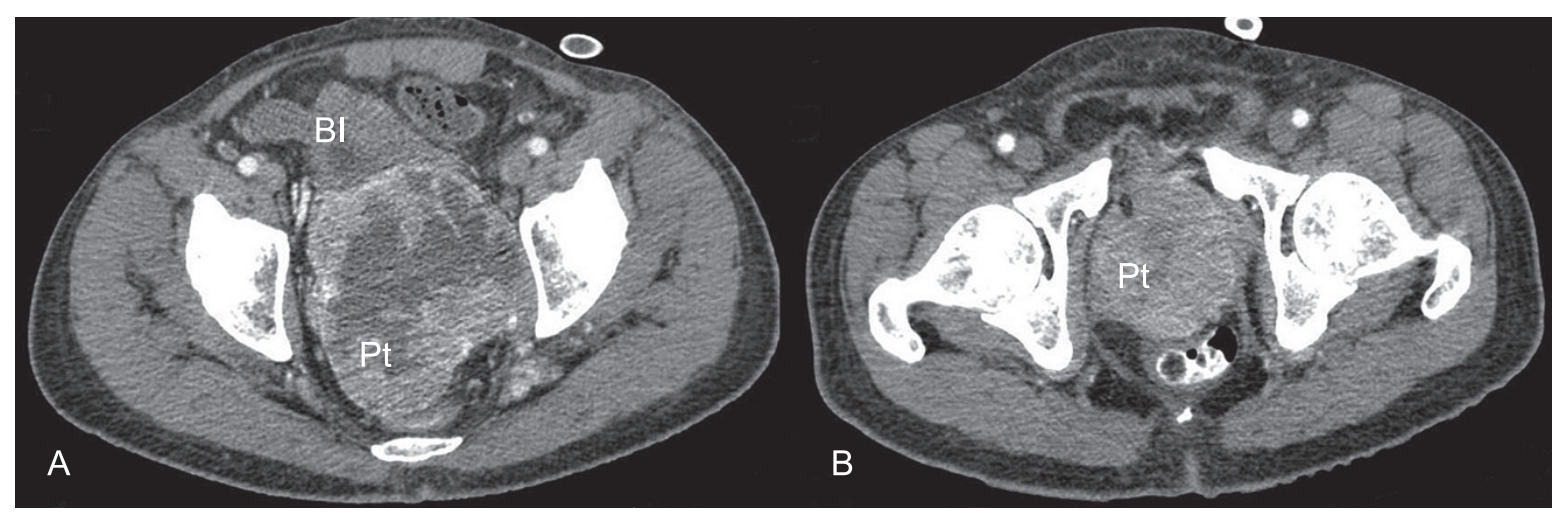

Figure 1 - Axial computed tomography of the pelvis showing a massive tumor, with well-defined borders, in the topography of the prostate. In $\mathbf{A}$, note the compression of the rectum and the bladder by the tumor. Pt: prostate; Bl: bladder.

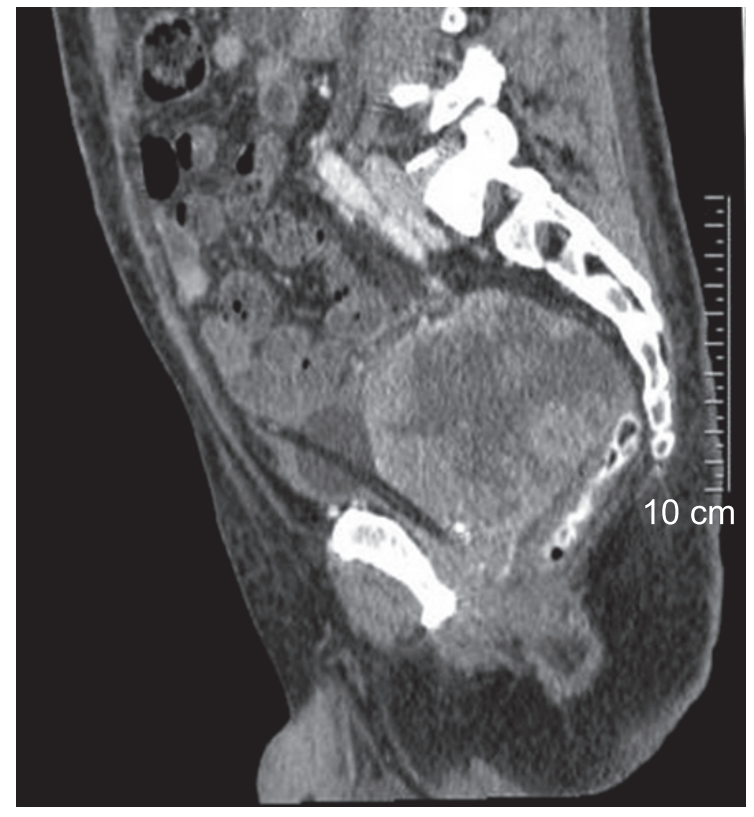

Figure 2 - Multidetector computed tomography of the abdomen and pelvis. Reformatted sagittal image showing a massive tumor occupying virtually all of the pelvic space. Note the heterogeneous distribution of the contrast medium.

The patient was submitted to transrectal prostate biopsy. Examination of the biopsy specimen revealed undifferentiated malignant neoplasia. The results of an immunohistochemical panel (Table 1) were consistent with malignant neoplasia, the pleomorphic and spindle cell characteristics of which were suggestive of high-grade sarcoma or sarcomatoid carcinoma.

Considering both diagnostic possibilities, the poor prognosis of both conditions, and the lack of any evidence-based treatment protocols, neoadjuvant chemotherapy and radiation therapy were initiated, with the objective of preparing the patient for subsequent surgical resection.

\section{DISCUSSION}

In the case reported here, the patient presented symptoms of urinary obstruction, an extremely enlarged prostate, and a low serum PSA level. In such cases, it is not uncommon for the patient to be misdiagnosed with prostatic hyperplasia. Despite the rarity of the condition, it is always advisable to include adenocarcinoma in the differential diagnosis of benign prostatic hyperplasia.

As in the case reported here, prostate biopsy specimens do not easily permit the differentiation between stromal tumors with spindle-cell morphology and poorly differentiated adenocarcinomas with a sarcomatoid component. ${ }^{1}$ A lack of awareness of this differential often delays the diagnosis, thereby compromising the treatment success and consequently worsening the prognosis. ${ }^{2-5}$

In the last two decades, numerous cases of rare carcinoma variants and stromal prostate cancer have been reported. ${ }^{2,3}$ We conducted a PubMed search using the search terms "prostate" and "sarcoma" and limited to studies published in English within the last 20 years and involving adults. We found twenty-five publications involving $<3$ patients, ${ }^{6-31}$ two involving 3-10 patients, ${ }^{2,4}$ and four involving $>10$ patients. ${ }^{1,3,32-34}$ The studies involving $\geq 5$ patients or more were considered representative and are summarized in Table 2. A second search, with the same limiters, was conducted using the search terms "prostate" and "sarcomatoid carcinoma". Twenty-seven papers were retrieved, only three of which involved $\geq 5$ patients..$^{10,11,35}$

Sarcoma of the prostate in adults is a rare disease that derives from non-epithelial mesenchymal components of the prostatic stroma. 
Table 1 - Immunohistochemical panel of the prostate biopsy specimen

\begin{tabular}{ccc}
\hline Antibody & Clone & Interpretation \\
\hline SMA & 1A4 & Positive \\
Vimentine & & Positive \\
HMB45 & HMB-45 & Negative \\
AE1-AE3 & AE1-AE3 & Negative \\
Desmine & D33 & Negative \\
S-100 & Polyclonal & Negative \\
34 beta E12 & 34 beta E12 & Negative \\
EMA & E29 & Positive \\
Calponine & Calp1 & Negative \\
CD34 & QBEnd-10 & Negative \\
Ki-67 & MIB01 & Positive in 25\% of cells \\
PSA & Calp1 & Negative \\
\hline
\end{tabular}

SMA = smooth muscle actin, EMA = epithelial membrane antigen, $\mathrm{PSA}=$ prostatic specific antigen .

Sarcomas account for $<5 \%$ of all genitourinary tumors and for only $0.01-0.02 \%$ of all prostate tumors. ${ }^{2,4}$

Sarcomas can be classified by histological subtype, cell differentiation, and tumor size. ${ }^{3}$ In cases of sarcoma of the prostate, the most common histological subtype is rhabdomyosarcoma followed by leiomyosarcoma, the latter being the most common subtype in adults. ${ }^{34,36}$

Sarcoma of the prostate grows rapidly, presenting as extensive pelvic tumors, leading to urinary tract obstruction, and typically has a poor prognosis. $^{2-5}$ In the case reported here, the clinical presentation consisted of symptoms of urinary obstruction and an initial CT scan of the topography of the prostate showed a massive heterogeneous mass that grew rapidly, despite the fact that the patient had a normal serum PSA level.

In the largest known study of sarcoma of the prostate, involving 21 patients, Sexton et al. ${ }^{2}$ found that $16(76 \%)$ had obstructive symptoms, $10(48 \%)$ had pelvic or perineal pain, and $7(33 \%)$ had irritative urinary symptoms. They also found that $5(24 \%)$ had a history of urinary retention. ${ }^{2}$ In patients with sarcoma of the prostate, the serum PSA level is almost always normal, because of the non-epithelial origin of the sarcoma. ${ }^{2,5}$ At diagnosis, the majority of such patients have symptoms of urinary obstruction, which, together with the normal PSA level, often result in a misdiagnosis of prostatic hyperplasia, which can lead to transurethral resection of the prostate, thus delaying the diagnosis of sarcoma. ${ }^{5,11}$

The largest series on sarcoma of the prostate retrieves data from 21 patients retrospectively reviewed along 3 decades. In the Sexton et al. study, the one-, three-, and five-year survival rates were $81 \%, 43 \%$, and $38 \%$, respectively. ${ }^{2}$ Longterm survival was mainly related to tumor-free surgical margins and the absence of metastatic disease at diagnosis. ${ }^{2}$ Neither tumor size nor grade (cell differentiation) have been shown to affect the prognosis, and there are conflicting data regarding the impact that the histological subtype has on the outcome. ${ }^{2,3}$ However, delayed diagnosis and advanced stage at the time of diagnosis have been shown to worsen the prognosis. , $^{47}$

Although there is as yet no consensus regarding the best treatment for sarcoma of the prostate, there is increasing evidence that a combined multimodal approach increases survival. ${ }^{2}$ Radical cystoprostatectomy is the recommended surgical procedure. Most studies suggest that the success rates are higher for the surgical approach than for other types of treatment used in isolation. . $37^{3}$ Complete resection with tumor-free margins provides the best prognosis-five-year survival of $67 \%$, compared with $0 \%$ when the surgical margins are invaded by tumor. ${ }^{1}$ These findings are similar to those obtained by Dotan et al., ${ }^{32}$ who studied cases of sarcoma of the genitourinary tract. The authors demonstrated a disease-specific five-year survival rate of $65 \%$ when complete resection was performed, compared with $21 \%$ for partial resection. ${ }^{32}$ Despite the lack of published evidence regarding adjuvant and neoadjuvant therapy, as well as that of prospective trials evaluating the impact of those therapies, it seems logical and understandable that a multimodal approach would improve outcomes. ${ }^{32}$

Sarcomatoid carcinoma of the prostate is even rarer than is sarcoma of the prostate and combines high-grade epithelial and sarcomatoid histological components. Although controversial, the epithelial and sarcomatoid components are currently thought to originate from a single cell. ${ }^{38} \mathrm{It}$ is possible that sarcomatoid carcinoma represents the evolution of an underlying adenocarcinoma into a lesion with associated sarcomatoid features and, in some cases, heterologous elements, resembling osteosarcoma, chondrosarcoma, and rhabdomyosarcoma ${ }^{36}$. Fewer than 100 cases have been reported, and there have been only three studies involving more than 10 patients. ${ }^{35,36,39}$ The 
Table 2 - Data from the last 20 years on sarcoma of the prostate: studies involving $\geq 5$ patients

\begin{tabular}{|c|c|c|c|c|c|c|c|c|}
\hline Year, author & Histology & $\mathbf{N}$ & $\begin{array}{l}\text { Mean } \\
\text { age, } \\
\text { years }\end{array}$ & Surgery & RT & ChT & $\begin{array}{l}5 \text {-year } \\
\text { survival }\end{array}$ & Follow up \\
\hline \multirow{3}{*}{$\begin{array}{l}\text { 1992, } \\
\text { Russo et al. }{ }^{34}\end{array}$} & Total & 10 & & 6 & $5^{*}$ & $1+5^{*}$ & NA & NA \\
\hline & Rhabdomyosarcoma & 5 & & $5^{*}$ & $5^{*}$ & $5^{*}$ & NA & NA \\
\hline & Leiomyosarcoma & 5 & & 1 & NA & NA & NA & NA \\
\hline $\begin{array}{c}\text { 1995, } \\
\text { Cheville et al. }{ }^{33}\end{array}$ & Leiomyosarcoma & 23 & 61 & $\begin{array}{c}\text { Varied: } \\
\text { usually } \\
\text { multi- } \\
\text { modal }\end{array}$ & NA & NA & $17 \%$ & $\begin{array}{l}30 \% \text { died from the tumor } \\
\text { in 3-72 months }\end{array}$ \\
\hline \multirow[t]{5}{*}{$\begin{array}{l}2000 \\
\text { Sexton et al. }{ }^{2}\end{array}$} & Total & 21 & 49 & 8 & 1 & 12 & $38 \%$ & $\begin{array}{c}8 \text { patients survived to } \\
81.5 \text { months }\end{array}$ \\
\hline & Leiomyosarcoma & 12 & & NA & NA & NA & $16 \%$ & $\begin{array}{l}75 \% \text { died from the } \\
\text { disease. One lost to } \\
\text { follow-up }\end{array}$ \\
\hline & Rhabdomyosarcoma & 4 & & NA & NA & NA & $75 \%$ & $\begin{array}{l}\text { No patients died, one } \\
\text { lost to follow-up }\end{array}$ \\
\hline & $\begin{array}{l}\text { Malignant fibrous } \\
\text { histiocytoma }\end{array}$ & 1 & & NA & NA & NA & $0 \%$ & NA \\
\hline & Unclassified sarcoma & 4 & & NA & NA & NA & $100 \%$ & NA \\
\hline \multirow{4}{*}{$\begin{array}{l}2006, \\
\text { Dotan et al. }{ }^{32}\end{array}$} & Total & 21 & 36 & NA & NA & NA & $29 \%$ & NA \\
\hline & Leiomyosarcoma & 8 & NA & NA & NA & NA & NA & NA \\
\hline & Rhabdomyosarcoma & 9 & NA & NA & NA & NA & NA & NA \\
\hline & Other & 4 & NA & NA & NA & NA & NA & NA \\
\hline \multirow{3}{*}{$\begin{array}{l}\text { 2008, } \\
\text { Ren et al. }{ }^{5}\end{array}$} & Total & 7 & 45 & 6 & $1^{\dagger}$ & $1^{\dagger}$ & NA & NA \\
\hline & Leiomyosarcoma & 5 & 56 & NA & NA & NA & & NA \\
\hline & Rhabdomyosarcoma & 2 & 21 & NA & NA & NA & NA & NA \\
\hline \multirow{4}{*}{$\begin{array}{l}2009 \\
\text { Janet et al. }\end{array}$} & Total & 5 & NA & NA & NA & NA & NA & NA \\
\hline & Rhabdomyosarcoma & 2 & 19 & 0 & 1 & 2 & $50 \%$ & 18.5 months \\
\hline & Leiomyosarcoma & 1 & 35 & 0 & 1 & 0 & $100 \%$ & 6 months \\
\hline & High grade & 2 & 49 & 2 & 1 & 1 & $100 \%$ & 15.5 months \\
\hline
\end{tabular}

RT: radiation therapy; ChT: chemotherapy; NA: not available. ${ }^{*}$ Multimodal therapy (surgery + ChT + RT); ${ }^{\dagger} \mathrm{ChT}+\mathrm{RT}$.

largest of those involved 42 patients. ${ }^{36}$ In that study, there was a history of prostate adenocarcinoma in $66 \%$ of the patients for whom clinical data were available and many patients were diagnosed with sarcomatoid carcinoma many years after having been diagnosed with acinar adenocarcinoma. Half of the patients showed a high Gleason score at diagnosis. ${ }^{36}$ Although some reports have raised the possibility that prior radiation or hormone therapy influences the development of sarcomatoid carcinoma, there is no consistent evidence of a correlation between treatment modality and disease progression. ${ }^{36}$ In fact, no clinical or pathological data have proven useful in stratifying cases of sarcomatoid carcinoma by prognosis. ${ }^{1,36}$
Sarcomatoid carcinoma of the prostate is an aggressive tumor with a poor prognosis. Similar to those of sarcoma of the prostate, the clinical manifestations of sarcomatoid carcinoma include filling and voiding defects. ${ }^{38}$ Progressive tumor enlargement can lead to bladder outlet obstruction and often requires multiple resections of the prostate in order to relieve the symptoms. ${ }^{1}$ For sarcomatoid carcinoma, there is no serum tumor marker, and patients with the condition present with PSA levels that are lower than would be expected, given the considerable size of the tumor. The low PSA levels might be due to the mesenchymal component. ${ }^{38}$ On palpation, the prostate is typically enlarged, nodular, and hard. Transrectal needle biopsy is usually 
diagnostic, and the differential diagnosis should include other conditions that combine malignant spindle-cell elements with epithelial components. In some cases, only sarcomatoid elements are seen. In such cases, the differential diagnosis should include pure sarcoma and pseudosarcoma. ${ }^{38}$ It should also be borne in mind that it is difficult to distinguish poorly differentiated adenocarcinoma with a sarcomatoid component from a primary mesenchymal tumor or benign prostatic hypertrophy. ${ }^{38}$

Regardless of the prostate tumor histology, CT and magnetic resonance imaging (MRI) are useful for showing the local extent of the disease and can inform the surgical planning. ${ }^{5,37}$ One recent study showed that sarcoma typically presents as a large, hypervascularized cystic tumor with heterogeneous soft-tissue enhancement in radiological studies (MRI and CT). The main MRI feature is a marked increase in the choline:citrate ratio, to a level higher than that observed in normal prostate tissue. ${ }^{5}$

The rarity of both types of prostate tumors discussed here might justify the difficulty in obtaining larger patient samples. Consequently, reliable data regarding treatment options and prognosis are scarce..$^{2,436}$ The histological heterogeneity of and lack of a standardized staging system for such tumors make it difficult to draw comparisons across studies. 2,4,32,37 Apparently, outcomes are worse for sarcomatoid carcinoma than for sarcoma. Although surgical resection is an option for localized tumors, only a few cases are operable at the time of presentation. After a diagnosis of sarcomatoid carcinoma of the prostate, the risk of death during the first year is $20 \% .^{1,36}$

Although the results of the immunohistochemical study of the case reported here did not allow us to differentiate between sarcomatoid carcinoma and high-grade sarcoma, we considered the latter diagnosis more suitable because of the clinical features (rapid growth of prostate, sudden onset of obstructive symptoms and very low PSA levels) and the lack of a history of prostate disease.

In the Surgery Department of the University of São Paulo University Hospital, 2,322 procedures involving the prostate, including biopsies and resections, were performed between 1990 and 2009. The present case was the only one identified as sarcoma of the prostate.
Sarcoma of the prostate is a major differential diagnosis in patients presenting with rapid prostate growth or extremely large prostate volume, accompanied by normal PSA values. A high level of suspicion is needed in order to avoid delaying the diagnosis and treatment.

\section{REFERENCES}

1. Zizi-Sermpetzoglou A, Savvaidou V, Tepelenis N, Galariotis N, Olympitis M, Stamatiou K. Sarcomatoid carcinoma of the prostate: a case report. Int J Clin Exp Pathol.2010;3(3):319-22. PMid:20224731. PMCid:2836510.

2. Sexton WJ, Lance RE, Reyes AO, Pisters PW, Tu SM, Pisters LL. Adult prostate sarcoma: the M.D. Anderson Cancer Center Experience. J Urol.2001;166(2):521-5. http:// dx.doi.org/10.1016/S0022-5347(05)65974-5

3. Janet NL, May AW, Akins RS. Sarcoma of the prostate: a single institutional review. Am J Clin Oncol.2009;32(1):27-9. PMid:19194120. http://dx.doi. org/10.1097/COC.0b013e31817b6061

4. Mondaini N, Palli D, Saieva C, et al. Clinical characteristics and overall survival in genitourinary sarcomas treated with curative intent: a multicenter study. Eur Urol.2005;47(4):468-73. PMid:15774243. http://dx.doi. org/10.1016/j.eururo.2004.09.013

5. Ren FY, Lu JP, Wang J, Ye JJ, Shao CW, Wang MJ. Adult prostate sarcoma: radiological-clinical correlation. Clin Radiol.2009;64(2):171-7. PMid:19103347. http://dx.doi. org/10.1016/j.crad.2008.07.013

6. Kim JY, Cho YM, Ro JY. Prostatic stromal sarcoma with rabdoid features. Ann Diagn Pathol.2010;14(6):453-6. PMid:21074696. http://dx.doi.org/10.1016/j.anndiagpath. 2009.10.008

7. Pace G, Pomante R, Vicentini C. Sarcoma of prostate: case report and review of the literature. Arch Ital Urol Androl.2010;82(2):105-8. PMid:20812534.

8. Niimi K, Hashimoto Y, Kurokawa S, Okada A, Tozawa K, Kohri K. Embryonal rhabdomyosarcoma of the prostate. Int J Clin Oncol.2010;15(1):93-6. PMid:20087615. http:// dx.doi.org/10.1007/s10147-009-0004-6

9. Funahashi $\mathrm{Y}$, Yoshino $\mathrm{Y}$, Hattori R. Ewing's sarcoma/ primitive neuroectodermal tumor of the prostate. Int J Urol.2009;16(9):769. PMid:19769660. http://dx.doi. org/10.1111/j.1442-2042.2009.02339.x

10. Rabbani F, Fine RG, D'Adamo D, Edgar M, Akin O, Paty $P$. Pure primary prostatic osteosarcoma arising in a nonirradiated prostateUrol Int.2009;83(2):236-8. 
11. Fraggetta F, Pepe P, Giunta ML, Aragona F. Primary high grade sarcoma of the specialised prostatic stroma: a case report with clinico-pathological considerations. Pathologica.2008;100(6):482-4. PMid:19475893.

12. Treetipsatit J, Kittikowit W, Zielenska M, Chaipipat $M$, Thorner PS, Shuangshoti S. Mixed embryonal/alveolar rhabdomyosarcoma of the prostate: report of a case with molecular genetic studies and literature review. Pediatr Dev Pathol.2009;12(5):383-9. PMid:19175284. http:// dx.doi.org/10.2350/08-08-0518.1

13. Jun L, Ke S, Zhaoming W, Linjie X, Xinru Y. Primary synovial sarcoma of the prostate: report of 2 cases and literature review. Int J Surg Pathol.2008;16(3):329-34. PMid:18387992. http://dx.doi.org/10.1177/1066896907309575

14. Talapatra K, Nemade B, Bhutani R, Kane S, Bakshi A, Muckaden MA, Laskar S. Recurrent episodes of hematuria: a rare presentation of leiomyosarcoma of prostate. $\mathrm{J}$ Cancer Res Ther.2006;2(4):212-4. PMid:17998709. http:// dx.doi.org/10.4103/0973-1482.29837

15. Abbas SM, Hill AG. Prostatic sarcoma after treatment of rectal cancer. World J Surg Oncol.2007;5:82. PMid:17663758. PMCid:1950882. http://dx.doi.org/10.1186/1477-7819-5-82

16. Miedler JD, Maclennan GT. Leiomyosarcoma of the prostate. J Urol.2007;178(2):668. PMid:17574619. http:// dx.doi.org/10.1016/j.juro.2007.05.036

17. Morikawa T, Goto A, Tomita K, et al. Recurrent prostatic stromal sarcoma with massive high-grade prostatic intraepithelial neoplasia. J Clin Pathol.2007;60(3):330-2. PMid:17347288. PMCid:1860576. http://dx.doi.org/10. 1136/jcp.2006.039032

18. Pan $\mathrm{CC}$, Chang $\mathrm{YH}$. Primary synovial sarcoma of the prostate. Histopathology.2006;48(3):321-3. PMid:16430486. http://dx.doi.org/10.1111/j.1365-2559.2005.02236.x

19. Chang YS, Chuang CK, Ng KF, Liao SK. Prostatic stromal sarcoma in a young adult: a case report. Arch Androl.2005;51(6):419-24. PMid:16214726. http://dx.doi. org/10.1080/014850190947822

20. Williams DH, Hua VN, Chowdhry AA, et al. Synovial sarcoma of the prostate. J Urol.2004;171(6 Pt 1):2376. PMid:15126828. http://dx.doi.org/10.1097/01. ju.0000125319.92634.9b

21. Froehner M, Bartholdt E, Meye A, Manseck A, Wirth MP. Adult prostate sarcoma diagnosed from tissue spontaneously excreted through the urethra. Urol Oncol.2004;22(2):119-20. http://dx.doi.org/10.1016/S10781439(03)00120-0

22. NabiG, DindaAK, DograPN.Primaryembryonal rhabdomyosarcoma of prostate in adults: diagnosis and management. Int Urol Nephrol.2002-2003;34(4):531-4. PMid:14577499. http://dx.doi.org/10.1023/A:1025638711476
23. Joerger M, Oehlschlegel C, Cerny T, Gillessen S. Postradiation high-grade myofibroblastics sarcoma of the prostate - a rare entity of prostatic tumor. Onkologie.2002;25(6):558-61. PMid:12566902. http://dx.doi. org/10.1159/000068628

24. Dalal DD, Tongaonkar HB, Krishnamurthy S, Kulkarni JN. Embryonal rhabdomyosarcoma of prostate in an adult-a diagnostic dilemma. Indian J Cancer.2000;37(1):50-3. PMid:11261237.

25. Nishiyama T, Ikarashi T, Terunuma M, Ishizaki S. Osteogenic sarcoma of the prostate. Int J Urol.2001;8(4):199-201. PMid:11260356. http://dx.doi.org/10.1046/j.1442-2042. 2001.00283.x

26. Probert JL, O'Rourke JS, Farrow R, Cox P. Stromal sarcoma of the prostate. Eur J Surg Oncol.2000;26(1):100-1. http://dx.doi.org/10.1053/ejso.1999.0749

27. Iwasaki $H$, Ishiguro $M$, Ohjimi $Y$, et al. Synovial sarcoma of the prostate with $t(X ; 18)(p 11.2 ; q 11)$. Am J Surg Pathol.1999;23(2):220-6. PMid:9989850. http://dx.doi. org/10.1097/00000478-199902000-00012

28. Beyzadeoglu M, Balkan M, Ozgök Y, Demiriz M, Pak Y. Prostate rhabdomyosarcoma in a young adult: a case study. Radiat Med.1997;15(3):199-201. PMid:9278381.

29. Lazar EB, Whitman GJ, Chew FS. Embryonal rhabdomyosarcoma of the prostate. AJR Am J Roentgenol.1996;166(1):72. PMid:8571909.

30. Atherton PJ, Stockdale AD, Rennie CD. Sarcoma of the prostate treated with radiotherapy. Clin Oncol (R Coll Radiol).1994;6(4):269-70. http://dx.doi.org/10.1016/S09366555(05)80299-7

31. Bos SD, Slaa ET. An adult man with a rhabdomyosarcoma of the prostate. A case report. Scand J Urol Nephrol.1991;25(4):329-30. PMid:1780713. http://dx.doi.org/ $10.3109 / 00365599109024571$

32. Dotan ZA, Tal R, Golijanin D, et al. Adult genitourinary sarcoma: the 25-year Memorial Sloan-Kettering experience. Urol.2006;176(5):2033-8; discussion 2038-9.

33. Cheville JC, Dundore PA, Nascimento AG, et al. Leiomyosarcoma of the prostate. Report of 23 cases. Cancer.1995;76(8):1422-7. http://dx.doi.org/ 10.1002/1097-0142(19951015)76:8\%3C1422::AIDCNCR2820760819\%3E3.0.CO;2-L

34. Russo P, Brady MS, Conlon L, et al. Adult urological sarcoma. J Urol.1992;147(4):1032-6; discussion 1036-7. PMid:1552580.

35. Dundore PA, Cheville JC, Nascimento AG, Farrow GM, Bostwick DG. Carcinosarcoma of the prostate. Report of 21 cases. Cancer.1995;76(6):1035-42. http://dx.doi. org/10.1002/1097-0142(19950915)76:6\%3C1035::AIDCNCR2820760618\%3E3.0.CO;2-8 
36. Hansel DE, Epstein JI. Sarcomatoid carcinoma of the prostate: a study of 42 cases. Am J Surg Pathol.2006;30(10):1316-21. PMid:17001164. http:// dx.doi.org/10.1097/01.pas.0000209838.92842.bf

37. Chang JM, Lee HJ, Lee SE, et al. Unusual tumours involving the prostate: radiological-pathological findings. $\mathrm{Br} \mathrm{J}$ Rad.2008;81(971):907-15. PMid:18662962. http://dx.doi. org/10.1259/bjr/68294775
38. Mazzucchelli R, Lopez-Beltran A, Cheng L, Scarpelli M, Kirkali Z, Montironi R. Rare and unusual histological variants of prostatic carcinoma: clinical significance. BJU Int.2008;102(10):1369-74. PMid:18793296.

39. Shannon RL, Ro JY, Grignon DJ, et al. Sarcomatoid carcinoma of the prostate. A clinicopathologic study of 12 patients. Cancer.1992;69(11):2676-82. http://dx.doi. org/10.1002/1097-0142(19920601)69:11\%3C2676::AIDCNCR2820691109\%3E3.0.CO;2-P

\section{Conflict of interest: None}

Submitted on: $27^{\text {th }}$ February 2012

Accept on: $3^{\text {rd }}$ March 2012

Correspondence: Divisão de Clínica Cirúrgica Av. Prof. Lineu Prestes, 2565 - Cidade Universitária - São Paulo/SP -Brazil CEP: 05508-000 - Phone: +55 (11) 3091-9291; 3091-9489

E-mail: oscareh@hu.usp.br 
